\title{
Recalibrating burdens of blame: anti-swidden politics and green governance in the Philippine Uplands
}

Authors:

Wolfram H. Dressler. Associate Professor, School of Geography, University of Melbourne, Australia. Email: wolfram.dressler@unimelb.edu.au

Will Smith, Research Fellow, Alfred Deakin Institute, Deakin University, Melbourne, Australia

Christian A. Kull. Professor, Institute of Geography and Sustainability, University of Lausanne, Switzerland

Rachel Carmenta, Frank Jackson Research Fellow, University of Cambridge Conservation Research Institute (UCCRI), University of Cambridge, United Kingdom

Juan M. Pulhin, Professor, Department of Social Forestry and Forest Governance, College of Forestry and Natural Resources, University of Philippines Los Baños, Philippines

This is an authors' version of this paper. The final version of record is published in Geoforum and is available here:

https://doi.org/10.1016/j.geoforum.2020.01.024

The citation of the paper is:

Dressler, W. H., Smith, W., Kull, C. A., Carmenta, R., \& Pulhin, J. M. (2020). Recalibrating burdens of blame: Anti-swidden politics and green governance in the Philippine Uplands. Geoforum. doi:10.1016/j.geoforum.2020.01.024 (volume and page numbers to be added once available)

\footnotetext{
ABSTRACT In Southeast Asia, the presence of cleared and burned forests has long evoked deep emotions, symbolism and representations that powerfully inform the governance of forests and upland peoples. In particular, the palpable visibility of shifting (swidden) agriculturalists 'slashing and burning' forests has fuelled centuries-old political agendas to criminalise swidden farmers for supposedly destroying swaths of forests valued for timber, biodiversity and now ecosystem services. Swidden farmers who regularly clear and burn forests, have endured a disproportionate burden of blame for investing in and maintaining an old livelihood practice into the $21^{\text {st }}$ Century. Drawing on Hall's politics of representation, we examine the contrasting political frames, management and practices of clearing and burning forests among upland farmers, state and non-state actors who govern forests on Palawan Island, the Philippines. We describe the social, economic, and biophysical character of swidden clearing and burning among the indigenous Tagbanua of central Palawan, whose livelihoods and landscapes are impacted by green governance and enclosures. Informed by several years of ethnographic fieldwork, we explore how and why Tagbanua farmers continue to clear and burn forest despite state and non-state actors criminalising these practices for decades. We argue that, despite sustained vilification and reduced fallows arising from governance policies and enclosures, Tagbanua farmers continue to clear and burn knowing well that, despite the practices
} 
being illegal, levels of tolerance and leniency toward swidden is the local norm, rather than exception-highlighting the importance of what we call 'atmospheres of consent'. Ethnoecological understandings of clearing and burning in the uplands, we argue, are crucial to recalibrating the burden of blame placed on poor farmers whose agriculture is deemed destructive by the region's burgeoning sustainability discourse.

Keywords: Philippines, swidden, criminalisation, resistant, ethnoecology, fire practices

\section{Introduction}

State, private sector, and civil society actors now work to govern and transform agrarian landscapes throughout Southeast Asia into 'higher value' modes of production under the guise of sustainability (Corson et al., 2013). Typically devolved subnationally, 'community-oriented' schemes aim to modify the behaviour and livelihoods of upland farmers with incentives and sanctions to curtail extensive land uses and intensify commodity production (e.g., from tree cropping to agro-industrial production). Aligning with and fueling such agendas, broader green governance and sustainable development agendas have expanded throughout insular Southeast Asia. Donor organisations, national agencies and civil society have combined older and newer rhetoric, branding and practices for the greening of rural sectors with initiatives that aim to mitigate greenhouse gases, conserve forest landscapes and reduce poverty in the uplands (The World Bank, 2012; UNEP, 2011). Diverse actors reproduce environmental governance discourses and practices by invoking new concepts and ideas - particularly market-based initiatives - that aim to draw financial value from 'intact' nature or exploit 'renewable' nature (Corson et al., 2013). However, no matter the initiative, such rural policy ambitions aim to turn upland farmers into modern subjects (Dressler, 2019).

Long castigated and criminalised as 'backwards' and 'destructive', swidden farmers (or shifting agriculturalists) — people who practice intermittent clearing and burning of forests for cultivation followed by a longer period of fallow-have much to lose at the intersection of environmental governance, conservation and development in Southeast Asia (Conklin, 1957; Fox et al., 2009). ${ }^{1}$ In the Philippines, in particular, state agencies have criminalised swidden for centuries (Dressler, 2009). Since the Spanish and American colonial era, state forestry departments have viewed swidden farmers as primitive 'anti-citizens' who, by virtue of ethnicity, location and agriculture, occupy a liminal, distant realm where modern rights are slow, if ever, to emerge (Agamben, 1995, 75). Colonial anti-swidden discourses and practices today fuel powerful sentiments

\footnotetext{
${ }^{1}$ The swidden agriculture that we describe most closely reflects what the early anthropological literature called an 'integral' practice (Conklin, 1957 et al.). Conklin (1957) defined integral swidden practices as central to and integrated with worldview, ritual, custom, labour and livelihood practices - swidden thus reflected a 'ritually sanctioned' way of life.
} 
against clearing and burning forests, which inform varied governance agendas in the Philippine uplands. As a result, burdened with the blame for shifting agriculture, swidden farmers must negotiate punitive sanctions against escape fires and greater responsibilities to manage agricultural burns. The semantics and sentiments of these long-sustained associations were, for example, heightened during the recent El Niño drought event in 2015-2016 that diminished rainfall activity in Southeast Asia and resulted in widespread fires throughout the Philippine archipelago (Mallari Jr \& Cinco, 2016; Mier, 2014). Several large fires broke out in prominent forested mountain ranges including Mount Apo in southern Mindanao, Mount Pulag in the Cordilleras and several areas of Palawan Island. In relatively recent media coverage, emotive imagery and language conflated these burns with swidden fires ravaging scarce and valuable forests in the uplands of Palawan. In 2015, for example, the front page of the national Philippine Inquirer read "Summer not all beach in Palawan; it is the season to burn forests", with the main body citing the anti-swidden rhetoric of a local environmental NGO:

"Last week showed 'an alarming increase in the incidence of slash-and-burn farming,' as poor families take to the forests to clear areas for planting [and] "every year it [kaingin] gets worse [... with] forests [bearing] the ugly scars of freshly burned patches".

https://newsinfo.inquirer.net/684378/summer-not-all-beach-in-palawan-it-is-the-season-to-burn-forests

Far from neutral, such language and imagery informs governance perceptions and actions (see Dressler, 2009). Juxtaposed against seemingly more environmentally benign and economically productive activities such as tourism and palm oil cultivation (Montefrio and Dressler, 2016), swidden (kaiñgin) and particularly fire continues to be represented in policy discourse and media as the main cause of deforestation and extensive burns, implicating indigenous peoples who live in these areas as the primary culprits of such destruction (Anda, 2015; Quitasol, 2016). However, despite a long history of state and non-state discourses and practices representing swidden as primitive and destructive, many uplanders continue to farm for life and livelihood (Dressler and Pulhin, 2009). As we show on Palawan, swidden farmers clear and burn forests with complex ethnoecological knowledge and practices informed by livelihood needs, social relations and forest ecology. As much as state bureaucracies and environmental NGOs continue to draw on discourses and practices that vilify and control swidden, one still finds upland farmers drawing on and investing in the shared meanings and practices necessary for swidden agriculture.

Our paper focuses on the discursive representations and socio-material practices involving swidden among Tagbanua farmers and forest governance in Palawan Island, the last forest frontier of the Philippines. The public and private sector actors orchestrating the island's green governance 
vision consider acts of clearing and burning forest as a direct threat to lowland plantations (e.g., palm oil), forest conservation (e.g., biodiversity and ecosystem services) and green aesthetics on the island (Dressler 2014). Reflecting a 'political economy of ignorance' (Dove, 1983), this range of governance ideals and interventions criminalises and rejects the ethnoecological benefits of swidden clearing and burning (Conklin, 1957; Kull, 2004). Our aim therefore is to detail how the social and biophysical functions of burning are central to swidden-based livelihoods and, how cautious burning practices enacted through a complex body of local knowledge stand in contrast to mainstream representations dominated by careless and wasteful burning (Therik, 2000, Rambo, 1980, Conklin, 1957; Nigh, 2008). In doing so, we move beyond the binary of state (and non-state) actors criminalising upland farmers for engaging in primitive swidden-induced forest burning and valorising lowland farmers for engaging in fixed-plot (low fire use) agriculture as productive and aligning with conservation. We detail an intermediate context in which the illegality of swidden reproduces a sense of risk, unease and hesitancy toward fire, and where local moral economies mediate its enforcement, enabling 'slashing and burning' to persist as a tolerated crime (see also Thung 2018). By emphasising this complexity, our paper aims to reaffirm the value of bridging critical political economy with ethnoecological analysis in political ecology more generally (see Haenn, 1999; Nazarea, 1999; Dove, 2011).

Our paper begins by outlining colonial and post-colonial governance policies that criminalise swidden farmers, and aim to curb swidden clearing and supress fire in the Philippine uplands. Focusing on the Palawan case, we then examine how recent governance policies and strictures ban, constrain, or marginalizing the use of fire, reduced fallows and limited forest cover in the context of the spatial constraints of enclosures, and broader prejudice against the use of fire. We contrast these governance interventions with an emic ethnoecology of firing practices to show how burning remains the most effective and efficient means to clear debris, replenish soils, and produce crops among poor upland farmers. Highlighting the role of local brokers, we show how clearing and burning remains a tolerated crime, where tolerance and leniency toward swidden remains the norm rather than exception.

\section{Methods}

This paper draws on field research carried out by the lead author in Barangay Cabayugan and in Puerto Princesa City (totalling 13 months across 2004- 2011, 2013, 2019), central Palawan. Mixed-methods involved participant observation, key-informant interviews and oral history discussions. In both areas, we interviewed (4) NGO and (2) state and (5) municipal representatives about forest governance practices, swidden management and fire suppression strategies. NGOs 
consisted of one indigenous rights organization and three environmental organizations, state actors included officials from the Department of Environment and Natural Resources (DENR) and subnational, municipal actors were rangers from the Puerto Princesa Subterranean River National Park, Palawan Island. Interviews with (30 individual) Tagbanua farmers were conducted in homes and fields, with questions covering the political, economic and the ethnoecological (knowledge, custom, and biophysical) dimensions of swidden clearing and burning (strategies, management etc). Drawing on Conklin's (1954) ethnoecological criteria for swidden analysis, we used key social, cultural, and biophysical categories to examine the ethnoecology of swidden fire as a core stage of swidden preparation. Using transect walks and mapped field inventories, farmers discussed the changing nature of swidden practices, the socio-spatial dimensions of burning (timing, strategies, management, results etc), the social value of burning, and localised responses to governance strictures. Interviews with female and male farmers ranged from one to two hours in length and were conducted individually and in small groups. Free, Prior and Informed Consent was secured for this research through a series of consultative meetings with indigenous leaders, community members, and local officials. Apart from well-known public officials, pseudonyms are used throughout.

\section{Recalibrating the 'burden of blame': valuing indigenous clearing and burning practices}

The socio-material character of the clearing and burning process makes it an intractable, incendiary political and ecological issue (Pyne 1997; Kull 2004; Thung 2018). The social, political and economic character of clearing and burning forests intersects with complex, multifaceted governance processes that inform contrasting representations and meanings of the value, use and place of swidden agriculture. Upland farmers clearing and burning of forests and fallows involves social, economic, physical and ecological dynamics that have been represented as distant, threatening, criminal and antithetical to the modern nation-state. Drawing on Stuart Hall's (1997) 'politics of representation', we describe how shared language, meanings, beliefs and actions toward something different reproduces and stabilises assumptions and dominant narratives (Hall 1985, 1997; Leach and Mearns, 1996; Kull 2004; To and Dressler, 2019). Hall (1997) argues that the politics of representation that feed and harden narratives almost always emerge through the relational practice of making and 'marking of difference' of the Other-e.g., indigenous uplanders (265). Such representational practices involve selecting and bridging certain language, meanings and imageries of the unfamiliar and unknown in ways that contrast, elevate and fix difference. For instance, dominant actors such as state foresters or local politicians may engage in the politics of representation by mobilizing public social fears and anxieties by accentuating those characteristics and practices of uplanders that are difficult for outsiders to understand and control. In time, the 
selection and meaning of certain language (e.g., tribu, tribal, bawal, prohibited) and practices (e.g., monitoring) become enmeshed and imbued with connotations that can inform the cultural production of difference. Such characterisations of the Other tend to produce and fix negative meanings and sentiments to legitimate practices of governance control. ${ }^{2}$ Swidden clearing and burning still invokes contrasting representations (semantics, words), practices (actions, signs) and meanings (survival, criminality, etc.) across variously positioned actors with discursive and material consequences for swidden farmers.

Yet such politics of representation are neither absolute nor hegemonic. They often also involve a range of contradictions that emerge through 'different specificities and temporal durations and the different modalities through which they function' (Hall 1985, 92). The representations of things and emerging narratives may shift depending on conjunctural politics and events of the time, where multiple influences, contradictions and circumstances give rise to new possibilities and constraints (Hall 2011, 705). Depending on the audience, location and context, dominant discourses and practices are subject to slippage and reinterpretation by those who produce and enact them and by those who are subject to them (see Leach and Fairhead, 2000). While political representations and practices do stabilise and endure, associated meanings, behaviours and outcomes always vary across social relations, political economy and institutional contexts. Knowledges and practices are thus coproduced and renegotiated across various actors in rural and urban settings.

While anti-swidden discourses and narratives stabilise and persist, they are also resisted and re-interpreted in the context of social relations being negotiated at the intersection of criminality, empathy and the need to burn. We show how anti-swidden discourses and practices have endured over the centuries in the Philippines, wherein colonial and post-colonial practices of representing swidden burning as unfamiliar and threatening have been entrenched in uneven relations of power. Despite the messy politics surrounding swidden agriculture - and its own ethnoecological complexity — state and non-state agencies have constructed swidden farming in terms of binary representations of destructive and criminal relative to modern, productive and legal lowland agriculture. As such anti-swidden representations circulate and manifest in state (and non-state) bureaucracies, agendas and programs, they come to frame, order and reproduce notional hierarchies of agriculture and peoples, in which swidden and uplanders lies at the bottom (Dressler, 2009). Such

\footnotetext{
2 Entman (1993) also refers to this as 'framing': the selection of 'some aspects of a perceived reality and mak[ing] them more salient in a communicating text [or practice] in such a way as to promote ... causal interpretation, moral evaluation, and/or treatment recommendation for the item described (52)
} 
representations have, in the process, generated a mounting burden of blame upon poor uplanders for most swidden-related problems (see Carmenta et al in review).

Anti-swidden narratives and burdens of blame have intensified as of late (Tacconi, 2016; Carmenta et al., 2019). As global climate change mitigation and biodiversity conservation measures aim to enhance forest cover (e.g., natural climate solutions, or REDD+) as forest conversion and climate change causes forests to dry out and become more susceptible to fire, the criminal nature of swidden clearing and burning is assumed a priori and considered a direct threat to green governance agendas (Dressler et al., 2018; Fletcher et al., 2018; Eloy et al., 2019). Swidden farmers now bear a mounting burden of 'fire risk' in increasingly flammable forest landscapes (e.g., drying out due to the greater prevalence of drought etc (see Smith 2018; Carmenta et al, in review; Eloy et al., 2019)) and are typically blamed when escape fires occur, irrespective of how close the fire is to where they reside (Carmenta et al., 2019).

Yet local burdens of blame vary in terms of how swidden strictures articulate with subsistence needs, moral economies, and levels of tolerance (Scott, 1977). The impacts and outcomes of local governance on swidden unfolds in terms of the negotiated politics of local enrolment in, and exclusion from, clearing and firing practices. In many cases, subnational, local actors (e.g., rangers or local leaders) work as brokers to translate and rework state and NGO discourses of blame in terms of both sanctions and tolerance among fellow swidden farmers. Such local brokers operate at the intersection of contrasting social relations, ways of knowing, and representations of swidden within and between rural farmers and bureaucrats. They work as active agents who create the relationships and roles needed to acquire knowledge and to secure authority to convey messages of what is and is not permissible in local and non-local contexts (Mosse and Lewis 2006). In marginal areas, where state rule can be liminal or fractured (Vasan 2002), local brokers often work as network specialists who understand the cultural nuances, rights and morality of the social worlds they negotiate and act upon (Vasan, 2002; Mosse and Lewis 2006). In some cases, brokers may change their title roles and practices, where a swidden farmer is 'retrained' as a park ranger or is 'socialised' as a local enforcer. Representing the state, organisations or 'their people', rangers or leaders have fluid political roles. They must be politically tactful and nuanced in order to convey the appropriate knowledge, information, and action that reflects the contrasting needs and concerns of their constituents without upending the relative calm (Wardell and Lund, 2006).

Local brokers mediate and soften the unpredictability and force of the state by reworking penalties and fines to suit local context (Kull, 2004). Or they simply 'let things go'. Typically living near or among those farmers who clear and burn forests, they understand how best to mediate 
enforcement and local livelihood needs. As we show, indigenous farmers negotiate swidden practices at the intersection of measures against and leniency toward swidden in the uplands - a broader process and impact consistent with 'atmospheres of consent'; that is, permission for something to happen or an agreement to do something. Local social relations and understandings facilitate consent not to clear and burn (in line with policies) and degrees of consent to clear and burn (in less mature forest), in line with rural empathy, identities and moral economies (Scott, 1977). We thus consider how upland farmers and rangers negotiate clearing and firing in such social atmospheres (Hall et al., 2011), where the ability to do both is governed through close social relations forged in the context of situated power, authority and legitimacy in rural settings. Crucial to this analysis is the social and material character of clearing and burning itself. The contested nature of clearing and burning in forested landscapes engenders uncertainties through which strictly defined anti-swidden policies are subject to mediation and blurred enforcement. Drawing on a critical ethnoecological lens, we show how swidden's complex character recalibrates the pervasive antiswidden politics and representations toward a more positive, empowering and socially just frame that values swidden emically in line with indigenous peoples' right to clear and burn on ancestral lands in the Philippines.

\section{Histories of swidden clearing, burning, criminalization and blame}

In much of Southeast Asia, the criminalization of swidden agriculture has long been informed by imagery and language emphasizing the potency of felled forests and the red flames that char and blacken tropical forest landscapes. The loss of timber through clearing and burning has, for centuries, occupied a central place in the minds of state foresters and efforts to eradicate swidden agriculture in the region (Boomgard 2007; Sivaramakrishnan 1999). In the Philippines, colonial and post-colonial states have had contested, tenuous relationships with swidden farmers. Spanish and American colonizers drew heavily on European religious, legal and scientific principles to classify forestlands, agriculture, and people, and criminalised those who farmed by clearing and burning forests in the uplands. Since 1521, the Spanish Crown defined upland areas as public domain or timberlands, where forest (timber) was vested to the colonial government and the Spanish Crown (Gatmaytan, 1992). Indigenous peoples who occupied these hinterland areas (often retreating from lowland Christians and Muslims) were considered primitive uplanders without title, whose swidden practices where deemed wasteful and destructive (Dressler, 2009). Even before the rise of scientific forestry institutions in the $19^{\text {th }}$ century, which positioned shifting cultivation in terms of resource decline, Spanish colonial officials understood indigenous swidden practices (kaiñgin) as backward agriculture. In the eyes of these officials, the rootless and seemingly 'simple' nature of kaingin 
placed it further down an imagined hierarchy of civilization that associated sedentary agriculture with Christianity (Scott 1974). In 1863, early control of swidden through the Inspeccion General de Montes drew on grassland succession theories to view fire as one of the primary ways in which forests were degraded. 'Kaingin', rather than commercial logging or plantation agriculture, was clearly identified by Spanish foresters as a source of forest conversion (Smith and Dressler, Forthcoming).

Following the transfer of the Philippines to American control in 1898, the colonial administration targeted clearing and burning more explicitly as an environmental and economic problem. Colonial foresters continued to value forests for exportable timber with little consideration for the social and subsistence value of swidden for uplanders. To secure timber reserves, the colonial government zoned valuable forests areas as timberlands in 1899 (Dressler, 2009). By 1903, the colonial Bureau of Forestry re-emphasized that swidden remained an impending threat to timber stands and by implementing anti-swidden legislation (e.g., the Kaingin Law of 1901), drew stiffer fines and prison sentences for swidden farmers. Alongside these legal structures, an emotive discourse of waste and destructiveness emerged surrounding the use of fire for swidden. As one Filipino forester emphasized: "untold forest wealth has been turned to ashes as a tribute to this scourge of the forest" (Nano, 1939: 87). It was American colonial foresters who identified fire as a distinct object of management that drove tropical deforestation and threatened the broader expansion of commercial timber harvesting (Smith and Dressler, forthcoming). Concerned with the spread and burning of imperata cylindrica grasslands (cogon) that emerges after successive swidden clearings in one area, for example, American forester, Harry Whitford (1911), noted that 'if the jungle growth is set on fire, as is frequently done, nearly all plants except the grasses are killed. In this way through many years vast areas of forest lands have been converted into cogonales, and repeated firings have prevented any change in their vegetation'. Informed by European notions of 'Scientific Forestry', the colonial period of forest and fire management thus gave legitimacy to post-colonial policies that further suppressed swidden clearing and burning as part of broader civilising missions in upland areas - the basis of reforming recalcitrant peasants into modern citizens (Masipiqueña et al., 2003).

After Philippine independence in 1946, state forestry officials' views of swidden remained relatively unchanged and continued to suppress the practice in the uplands. Like the Americans, the Philippine state considered clearing and burning as an 'external disturbance' emerging from marginal spaces that needed to be managed and controlled rather than something fundamental to forest ecology and landscape change (Smith and Dressler, forthcoming). In particular, viewing the selfpropagating, efficient and destructive character of fire as a threat to 'progress' in the uplands, 
foresters and conservationists worked hard to control it with modern methods (see Pyne 1997).

The Bureau of Forestry secured further control over " "kaingineros" [sic] by drafting a Revised Kaiñgin Law in 1963 (Scott, 1979), stating that swidden farmers should be identified, managed and/or resettled (Population Center Foundation, 1980, 11). In 1975, Marcos's Presidential Decree (PD) 705 regulated swidden by reclassifying the management and use of public forests as timberlands and forest reserves and indirectly supported the resettlement of 'squatters' (Population Center Foundation, 1980). Other social forestry policies offered farmers de facto tenure with 25-year leases based on expectations that swiddens would be inter-cropped, ending the rotational clearing and burning of forests (Sajise, 1998). After Marcos's fall, bias against fire and the mobility of swidden farmers continued to inform newer, less punitive efforts (e.g., promotion of fixed-form, sedentary agroforestry) to reconfigure upland livelihoods rather than requiring the expulsion of smallholders from state forests (Dressler, 2009).

While the revised Constitution (1987) gave state agencies and civil society greater political space to integrate social equity and livelihood considerations with forest conservation, most state agencies simply 'devolved' anti-swidden discourses and regulations to subnational agencies and nongovernmental organizations (NGOs) (see Dressler, 2014). Legislative reforms and devolution through the Local Government Code (1992) did not necessarily recalibrate the state's negative representations of indigenous peoples and swidden agriculture. Despite civil society flourishing post-Marcos, it was grass-roots indigenous and environmental NGOs (e.g., the Indigenous Peoples' Apostolate (IPA), Legal Resources Center (LRC)) who defended indigenous peoples' rights to farm swidden, whereas the better funded, media-savvy mainstream environmental NGOs tended to vilify swidden as much as state agencies did (Fletcher et al., 2019). As much as progressive legislation such as the Indigenous People Rights Act (IPRA, 1997) offered indigenous people rights to ancestral domain claims and titles (CADC, CADT) and the National Integrated Protected Areas Strategy (NIPAS, 1992) supported devolved, community-based initiatives, the status-quo of misrepresenting and over-regulating swidden has remained and become even more extensive through communityoriented initiatives (see the Community-based Forest Management (CBFM) initiative of 1995). Fire prevention and protection, for example, were nominally devolved during this era to Local Government Units (LGUs), particularly municipalities and barangays. As a result, anti-fire policies have become part of local institutions and community-based initiatives, facilitating closer monitoring of swidden burning with a range of sanctions (Masipiqueña et al 2003).

Today, managing and criminalizing swidden occurs in the context of varied forest 
governance programs, protected areas, and plantation regimes situated in a deepening environmental bureaucracy and political economy in the Philippines. We discuss below how dominant antiswidden narratives continue to inform recent efforts to eradicate felling and firing from the forests of central Palawan.

\section{Suppressing swidden, atmospheres of consent, and a burning persistence}

Since the late 1980s, Palawan Island has emerged as a biodiversity hotspot with forest cover subject to green governance, enclosures and rising extractivism. In the early 1990s, national government agencies devolved authority over resource management to the City (municipal) Government of Puerto Princesa, and in time, established the Strategic Environmental Plan (SEP 1992) headed by the Palawan Council for Sustainable Development (PCSD) and its partners. The latter's main policy instrument, the Environmental Critical Areas Network (ECAN) zoning system, aimed to direct regulatory activities in discrete land use categories, attempting to control the extent and location of swidden and fire across the island (Dressler, 2009). At the same time, both indigenous and environmental NGOs worked together with the Provincial Department of Environment and Natural Resources (DENR) to secure 'Certificates of Ancestral Domain Claim' (CADC) and eventually 'ancestral domain title' (CADT) for indigenous residents on Palawan and elsewhere in the country. With CADTs demarcated, indigenous peoples were supposedly given titled land holdings to control access to and use of land and forest resources and ultimately engage in swidden with fewer impediments and constraints than decades earlier.

Overlapping with CADTs across Palawan, multilateral institutions, state agencies, LGUs, and NGOs have designed protected areas and programs that continue to curb swidden and reinforce transitions to sedentary agriculture. Global governance policies and programmes - including a European Union funded REDD+ scheme (Reducing Emissions from Deforestation and Degradation plus) and the World Bank's natural capital accounting program, Phil-WAVES (Wealth Accounting and Valuing Ecosystem Services) — are now also working through state and non-state policies and interventions to advocate for sedentary agriculture to replace swidden, fallow lands and the need to burn. In this context, forest governance initiatives, environmental programs and corporations have increasingly advocated for market-based schemes and incentives to facilitate 'added value' agriculture to curb swidden clearing and burning.

Our case in central Palawan describes next how Community Environment and Natural Resources Officers (CENRO), municipal actors, park rangers and local leaders monitor and curb swidden clearing and firing by way of social relations and different policies (e.g., zero and controlled burning ordinances) inside of a celebrated protected area. Our case contrasts local government 
efforts to suppress swidden clearing and burning as destructive and backwards activities against Tagbanua knowledge, needs and desires to clear and burn forests.

\section{Cabayugan, Puerto Princesa City, central Palawan}

Flanked by migrants living along main roads and increasingly co-mingling with new migrant farmers upland (who often burn extensively to claim land), the indigenous Tagbanua ${ }^{3}$ and Batak $^{4}$ peoples coexist in the agro-ecologically diverse uplands and valleys of central Palawan. In the northern barangays of the municipality of Puerto Princesa City, both indigenous peoples rely on swidden-based livelihoods within CADT lands (in Kayasan, 7,530 ha, 1996 and in Cabayugan, 4,460 ha, 1997).

The Tagbanua (described in the case below) and Batak draw on a mixed-livelihood portfolio, wherein swidden cultivation remains central (e.g., swidden crops (upland dry rice) and fallow crops (cassava, sweet potato etc), non-timber forest products (NTFPs) (rattan, honey etc), coastal-marine harvests, off- and on-farm labour, etc). More focused on sedentary agriculture than the Batak, the Tagbanua have traditionally specialised in swidden farming as an integral social, cultural and economic practice (see Fox 1952; Conklin 1957). While many remote households still invest in longer-fallow swidden for livelihoods and customs, the majority experience shorter fallows, less crop diversity, and lower yields as part of their own (and others') drive to intensify and sedentarise livelihoods. Many Tagbanua now rely heavily on the cash income derived from exploiting NTFPs, the live reef fish for food trade, paddy rice cultivation, cash crop production (e.g., rubber, oil palm), daily labour and credit (Dressler and Fabinyi, 2011). Rather than aligning with any discrete category of horticulturalist, forager or hunter-gatherers, they (and the Batak) have long pursued 'multiplex' livelihoods (Bryceson, 2002) in patchy landscape mosaics that cut through older uplandlowland/forest-farm divides (see Dressler et al., 2016).

\footnotetext{
${ }^{3}$ The Tagbanua of central Palawan are of Malay descent and known as Apurhano, whose origin stems from Aborlan and Napsaan (Fox, 1954). Two other Tagbanua groups, the Tandualnen and Calamian, are in northern reaches of the island and the Calamianes island group. Indigenous to the island since pre-colonial times, they have long been erstwhile swidden farmers who have occupied the coastal plains and uplands of Palawan.

${ }^{4}$ The Batak are characterised as a reclusive, forest-dependent indigenous peoples engaged in livelihoods at the 'foragefarming' interface who, over time, have retreated further into the uplands due to encroachment from migrant farmers and broader governance pressures (Novellino, 2011). Once holding extensive ancestral territories, Batak now live in small village clusters from where they draw on surrounding landscapes for swidden with diverse traditional rice landraces, a high diversity of root crops, as well as varied flora and fauna for subsistence, trade and sale (ibid).
} 


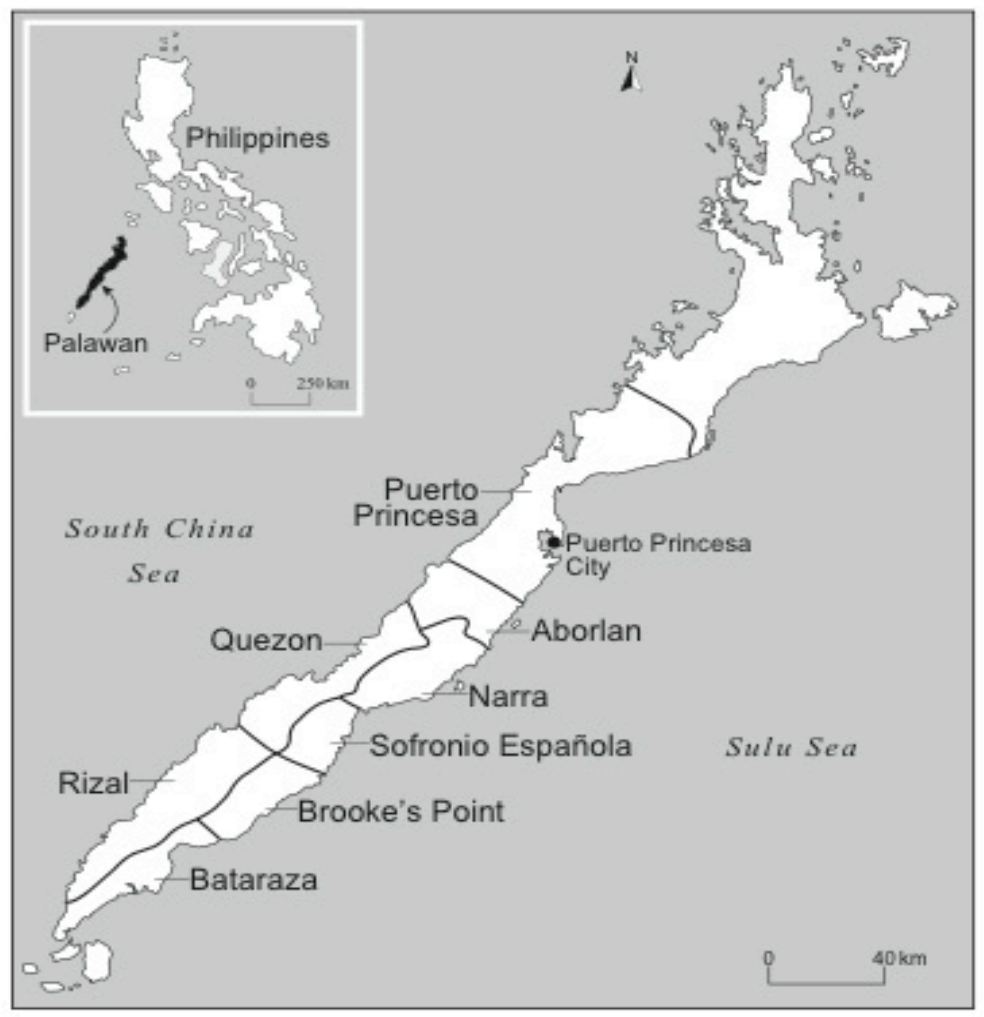

Map 1: Palawan Island, the Philippines

In the last decade or so, various charismatic City mayors-from Ed Hagedorn to Lucilo Bayron - have bolstered Puerto Princesa City's environmental branding and bureaucracy to legislate against and criminalise swidden clearing and burning in areas overlapping Tagbanua and Batak ancestral domains. Leveraged through the now-world famous Puerto Princesa Subterranean River National Park (PPSRNP, est. in 1971) and its management drive to keep forest cover intact for ecotourism, the then City Mayor, Hagedorn, banned the clearing and burning of forest for swidden as part of his successful bid to expand the national park (to 22,202 ha) as a World Heritage Site in 1999. Promoting the island, the municipality and the park as a major 'ecotourism' destination, Mayor Hagedorn's city government established a 'Zero-Burning' Ordinance in 1994 for all of Puerto Princesa City. Armed with the ordinance, park rangers and foresters implemented the stricture with corresponding fines. Despite living in ancestral domains claims within the park buffer zone, many Tagbanua and Batak tended to follow the anti-fire stricture, and, without proper burning, went hungry after failing to produce a sufficient rice harvest that season. Farmer protests and petitions from grass-roots indigenous and environmental NGOs (e.g., the Indigenous People's Apostolate (IPA) and the indigenous peoples federation of Palawan, NATRIPAL, Nagkakaisang mga Tribu ng 
Palawan, and the Environmental Legal Assistance Centre (ELAC)) prompted the mayor and the City Government to change the policy to a 'Controlled Burning' Ordinance (No. 110-94) and provide 'calamity rice' to those communities experiencing rice shortages and hunger due to the ban (Novellino and Dressler, 2009).

Nothing much has changed since then. Against a backdrop of environmental NGOs and government pressures to curb swidden burning across the island, renewed forest governance pressures in the buffer zone of the park continue to suppress swidden clearing and burning, only to reinforce livelihood insecurity among poor uplanders. Hagedorn's mandate has been sustained by a variety of elements that continue to represent swidden clearing and burning in a negative light. These include various anti-swidden media reports, the Mayor of Brookes Point in southern Palawan attempting to draft similar anti-fire legislation, and a long-standing Puerto Princesa City municipal mandate of suppressing fire. Such politics of representation informs PPSRNP management strategies and particularly who becomes trained as a ranger and how they broker in buffer zone forests. While most rangers are Christian migrants, some indigenous residents who farm swidden have also been trained as park rangers as part of the management board's indigenous stewardship and employment initiative (see Dressler 2009). On the one hand, they cite the official script of needing to prohibit (bawal) clearing and burning for fear this will destroy (sera) the lush forests park managers depend upon for drawing tourists (revenue) and conserving biodiversity. On the other, they draw on local scripts with some empathy, noting that those who burn only do so in order to feed themselves and their families, hearing the common farmer refrain of "kung walang kaingin, magiging gutom ako (with no swidden, I'll go hungry). Multiple interviews with park rangers in 2019 confirm such 'double speak', particularly with Tagbanua rangers. Having worked as a ranger for three years now, the Tagbanua, Marlos Jagmis, contrasted his empathy with the need to burn against the illegality of clearing and burning forests for swidden in the national park, even when within the ancestral domain title: ${ }^{5}$

"The purpose of kaingin for indigenous peoples (IPs) like me is to make our plants healthy and productive. That's the very reason why we all have to burn. With a burn our rice becomes healthy; the burned leaves fertilize the soil."

"But even though it is our traditional belief, since the site is in a protected area, even if it is within the CADT (Certificate of ancestral Domain Title), burning still needs to be restricted. Burning still has a significant impact. If the bigger trees are burned, especially those adjacent to underground river, the river will be dried up if the trees are cut. That is the effect of burning."

\footnotetext{
${ }^{5}$ Key informant interview, Marlos Jagmis, PPSRNP Buffer Zone, June 2019
} 
Another ranger, Raul Masipag, noted similarly: ${ }^{6}$

'I work as a ranger... and I guard the forest. For me, I see the burning and it's illegal here because it's in a protected area; continuous clearing for kaingin will degrade the area which is now a World Heritage Area. This town here is in the park, so we have to prohibit kaingin. Kaiñgin has a big impact here, so it is better they choose another livelihood.

But we also understand they need to clear and burn for a good harvest-they need to eat. But I hope that others will give them other work. Even if they have a CADT, they should not be doing kaingin in there. If people want to do kaingin and burn, they need to coordinate with the DENR and Barangay officials to let them know where and what type of burn it will be.

If we see a group of farmers, we will also talk to them before they begin to burn, and we really emphasize that they should only do under-brushing, to clean below the plants and not burn.

The park and some of the NGOs offer different workshops and livelihood support like livestock raising and vegetable gardens to help them move away from kaingin... some of the kaingineros are even employed by the park.'

A long-term ranger, Manod Mantap repeats the above with less empathy that ${ }^{7}$ :

'The laws say that we should be strict with kaingin... it should be prohibited based on the laws of the DENR. Secondary growth should not be burned as the fire can spread....

There's about 7 of us who patrol on 4-day shifts (per month) and ....if the IPs [indigenous person] cuts a tree greater than $15 \mathrm{~cm}$ in diameter then we discuss with the Barangay officials and possibly file a complaint with the DENR. ....but we don't issue fines here for IPs. We go to the area were fresh cut is and we often wait to deal with the offender on site. We have a zero burning policy here at the park...'

In many cases, however, park rangers turn a blind eye to Tagbanua farmers clearing and burning younger secondary growth forest, noting that swidden is often a sole source of livelihood. As shown below, the use of a fire break (gahit) in particular tends to appease rangers, with one ranger noting: "they need to clear two metres around their field and also guard the fire.... So rather than completely stopping kaingin fire we aim to control it, especially if katutubo [indigenous peoples] are involved". In such circumstances, despite the perceived illegality of swidden firing, most farmers only receive a verbal warning to monitor their fire carefully and to end the burning as soon as possible. Informal discussions and verbal reprimands about burning (or any infraction) are most common amongst those rangers and farmers who have known each other for a several years

\footnotetext{
${ }^{6}$ Key informant interview, Raul Masipag, PPSRNP Buffer Zone, June 2019

${ }^{7}$ Key informant interview, Manod Mantap, PPSRNP Buffer Zone, June 2019
} 
already. Frequently sharing small talk, a coffee or tagay-tagay ${ }^{8}$ with gin makes patrols across many households a social affair, which softens infractions or leads to deals concerning outcomes. In such rural settings, socially acceptable enforcement outcomes matter.

In most cases, it is not Tagbanua but new migrants entering or settling in the park buffer zone (and or CADTs) who claim and burn larger areas of forest to claim land without any firebreaks and monitoring. As one ranger noted: "There are many migrants involved in burning, in fact most of them are migrants who do not know the protected area law; the residents here for a longer time are already aware of the restrictions... it is migrants from Mindanao and Bisayas who are more aggressive in opening the forested areas, maybe because they are looking for land to occupy". 9 In such cases park rangers appointed local or indigenous 'community organizers' to double up on brokering and information dissemination efforts on the illegality of such brazen land claims. As the ranger noted, Tagbanua community organizers will engage in a "house-to-house campaign because every area here is in the protected area.... They are responsible for informing/orienting people on the laws and prohibitions" (ibid).

Apart from migrant and indigenous rangers, Tagbanua leaders and farmers also broker fellow farmers' clearings and burns, rendering swidden undesirable but tolerable. Recruited by CENRO, NGOs, and Barangay officials as local brokers and enforcers, they have disciplined fellow farmers in terms of where they can or cannot clear and burn forest for swidden, despite many believing they can do both with fewer restrictions in their ancestral domain (CADT). Often, for example, as their CADT representatives, prominent Tagbanua are appointed to protected area management boards (PAMBs), and, ultimately, become appointed as local brokers for community, NGOs and the PAMB. Responsible for translating management rhetoric, these Tagbanua brokers are charged with convincing fellow farmers that swidden is less productive than other livelihood practices and, if practiced anyway, then it should be in less mature forest. One charismatic, well networked Tagbanua broker, Celso Pimental, who had long been the 'go to' person for NGOs, rangers and $\mathrm{PAMB}$, sought to convince his fellow farmers to uphold his recently adopted belief that 'we're only allowed to cultivate swidden in latian (secondary growth) and not in giba (old growth)'. In some cases, Celso and his family, hailing from a 'high blood' kin line, would organise impromptu community meetings to discuss new park projects and invariably the number of households (whether migrant or Tagbanua) cultivating swidden in the CADT, typically on the park's and DENR's behest.

\footnotetext{
${ }^{8}$ Tagay-tagay (or simply Tagay! Cheers!) is a customary Filipino drinking affair involving the sharing of shot rounds with everyone drinking from one glass, with a tanggero (who fills the shot glass) ensuring everyone has their fill. A ranger and several farmers engaged in tagay-tagay denotes goodwill and camaraderie.

${ }^{9}$ Key informant interview, Raul Buntar, PPSRNP Buffer Zone, June 2019
} 
As unrelated Tagbanua farmer noted, 'we attended a meeting arranged by Celso who told us not to clear the larger trees in the forest...'. Sometime earlier, Celso went even further by nailing a homemade sign to tree in the CADT declaring that swidden must not be cultivated in giba. Such tandem practices of enrolment and exclusion dissuades farmers from clearing older forest, compelling then to intensify swiddens and burn less (Dressler 2014). In other cases, as noted, local anti-fire enforcers also work with the Department of Environment and Natural Resources office (DENR) and Barangay police to tell farmers not to clear and burn forests for their swidden. As one farmer noted: 'The barangay police told me to stop burning and the PASU also held a meeting in Purok Bantod; it was DENR facilitated' ${ }^{10}$ Another farmer similarly noted: 'The DENR and others from here told us not to clear and burn old growth forest. Danny organised a meeting on swidden management and told us what we could not do.,11

Yet while such enforcement ideals reflect broader anti-swidden politics, intentions and outcomes seldom neatly align in this socially uneven but well-connected barangay. Most enforcement impacts are far from absolute. While more and more Tagbanua farmers limit the size and location of swiddens, consenting to some strictures, cultivating swidden typically remains a tolerated crime and so continues (see also Mathews, 2008). Often, the very Tagbanua leaders enforcing the PPSRNP, DENR and barangay's access strictures will clear and burn swaths of forest for swiddens, only to tell their neighbours to stop a day later. Indeed, while Celso Pamintel 'the broker' had shifted to agroforestry-type fields, he also held a half-hectare of swidden abutting his own paddy field. In cases where a Tagbanua leader or park ranger apprehend a fellow farmer for clearing and burning a swidden 'illegally', they tend to deal with them informally on the margins of the law. In most cases, a ranger issues a socially symbolic reprimand to farmers for an initial infraction of clearing and burning older forest. For example, one park ranger who regularly traverses the forests of Cabayugan noted that:

'To find kaingin and burn areas, we usually rely on community members who will tell us where, and we will go if it's a wide area being burned. This is usually how we get information. So, for the first offense, we usually issue one warning and ask: "Why did you cut this tree?" If a second time, we might file a complaint and on a third occasion, we might confiscate their equipment. ${ }^{, 12}$

It is seldom that anyone notices when fields are cleared and burned in younger secondary

\footnotetext{
${ }^{10}$ Key informant interview, Hiraldo Nanod, April 6, 2013

${ }^{11}$ Key informant interview, Manong Manlap, April 62013

${ }^{12}$ Key informant interview, Raul Masipag, PPSRNP Buffer Zone, June 5, 2011
} 
forest or degraded brush lands. Other park officials followed a similarly lenient stance, with a Tagbanua farmer noting that:

'It is not illegal to do kaingin as long as it's in second growth forest and we use a fire break so that we contain the fire. This is what the park officials said during a meeting at the barangay hall... they usually leave us alone. ${ }^{13}$

And another farmer spoke similarly with more defiance:

'Kaingin provides us with traditional foods', we will get a good harvest if we burn and clean in and around the plants that we've planted.

The bantay gubat [forest guards] told us that it was illegal to clear in old growth, but not in latian [secondary growth]; so long as we use a firebreak around the field it is ok for them. So, I will continue to clear and burn in latian, but will not clear the larger trees in the area'. ${ }^{14}$

A final farmer noted:

'We had a seminar about irrigation but not about kaingin. We had many seminars in the CADT before about the need not to clear and burn in old growth... but they also taught us how to make better fire breaks when we clear in second growth'. ${ }^{15}$

In this context, then, Tagbanua continue to clear and burn for swidden out of need, norm and necessity in intensively governed buffer zones, and while anti-fire strictures are tangentially enforced, they are pursued with empathy and by turning a blind-eye to smaller swidden burns, and those burns done 'responsibly'.

\section{Swidden persistence: clearing and burning ethnoecologies}

The perspectives and practices of park rangers, DENR and local brokers, which ambivalently position clearing and burning as a source of degradation, are challenged by farmers themselves. In contrast to the anti-swidden discourses circulating in buffer zones and elsewhere, Tagbanua farmers hold complex ethnoecological knowledge about clearing and burning that mediates anti-swidden enforcement and sustains swidden agriculture (see Peters and Neuenschwander, 1988). In this sense, what farmers do, how they do it, and how they speak of it, offers a counter-narrative to how swidden is vilified on Palawan today.

\footnotetext{
${ }^{13}$ Key informant interview, Jonah Antonio, Dec 11, 2011

${ }^{14}$ Key informant interview, Joselito Rizal, Dec 12, 2011

${ }^{15}$ Key Informant Interview, Cristano Vedasto, March 30, 2010
} 
Drawing on Conklin's (1954) swidden 'folk taxonomy', the following represents a partial window into the clearing and burning ethnoecologies of Tagbanua farmers. Drawing on field visits and interviews, it describes, in particular, how their knowledge and practices of burning align with the social and biophysical characteristics of swidden and livelihood needs. While these strategies reflect characteristics unique to Palawan, they also contain many elements that would be familiar to swidden farmers elsewhere in Southeast Asia, the Pacific islands, Africa, and Latin America (see Peters and Neuenschwander, 1988; Kull, 2004; Carmenta et al, 2013; Thaler et al., 2017; Thung, 2018). As the evidence shows, swidden farmers do not clear and burn as indiscriminately as state foresters, park rangers and NGOs might suggest. Rather, they draw on complex swidden ethnoecologies that make clearing and burning a well-honed practice that can often be done carefully and sustainably.

\section{Clearing forests and Timing of burn}

Forest clearing happens between late January and February, in anticipation of the northeastern monsoon (Amihan) that broadly determines the extended dry season between January and May. Most Tagbanua farmers typically burn in March, long considered the 'hottest' month, with rain often delaying the 'peak burning' time until sometime between April and May. This ensures that rice seeds and other crops are planted before the southwestern monsoon (Habagat) brings rains between June and August. After a sequenced clearing of smaller trees (with machete, bolo) and then larger trees (with axe, palakol, and stilted flute ladders) now typically in second growth (latian, bunglay) (and seldom in older forest (giba, cf Warner 1979), farmers dry felled debris for several days or weeks depending on the amount of rainfall and moisture of the debris. (In earlier times it was not uncommon for a Tagbanua woman to have her own swidden in small bush or tree cover (lomun) (see Warner 1979). As Vilmar Drago notes, 'the best time to burn is when it is hot -at noon-and when the wood is at its driest point ... it must not have rained in the last 2-3 weeks.' Distinguished elder, Manong Timban, suggests that:

'...we know when to burn based on how dry the soil is and how the leaves and bark crackle. Yes, I know when to burn: if the leaves on the ground are dry, we burn, if the leaves still look dark, then I know it is still wet and won't burn; this means that fire won't burn the wood properly from below. The debris on the ground must be dry so fire moves from below and up. If everything below is dry, then the fire will really go and burn everything'.

Elicia Corzod similarly emphasises that after about three weeks, her field is dry enough to burn when: 'leaves of the plants are dry enough [and] they will break in your hands.' As she and other suggest, it is the type and age of forest cleared that determines the character of debris, the 
length of time required to dry the debris, and the frequency and type of burn that is necessary. Younger forests (e.g., brush and young secondary growth mixed with bamboo) are often much more combustible; they dry out quickly and burn through efficiently, though return fewer nutrients to soils. Depending on debris placement, one or more burns over a shorter period of time are needed to clear a field. In contrast, mature secondary and old growth forests (biomass and soils) tend to be moister, have larger trees (width and length) and massive root systems that require multiple, hot burns and frequent direct (applied) burns over several days or even one to two weeks (see below).

\section{The Art of Ignition}

While many farmers burn in a particular manner, with their own firebrand and strategy, the first burn is always influenced by the interplay of slope, debris, and wind. Manong Timbang burns his relatively flat field from the edges to the middle, using flammable saheng resin (dagda,Tag, Canarium asperum) affixed to bamboo (buho) stalks:

'... I attach saheng to the end of buho (bamboo) and then light it...the resin burns as it drips. I burn from edges of the field, so the fire is blown to the inside. We begin the burn from whichever direction the wind blows; so, the fire is carried in the direction of the wind. Mostly we just use a big piece of bamboo as our fire starter'. 
Plate 1: Manong Timbang, with Saheng, burning Saheng
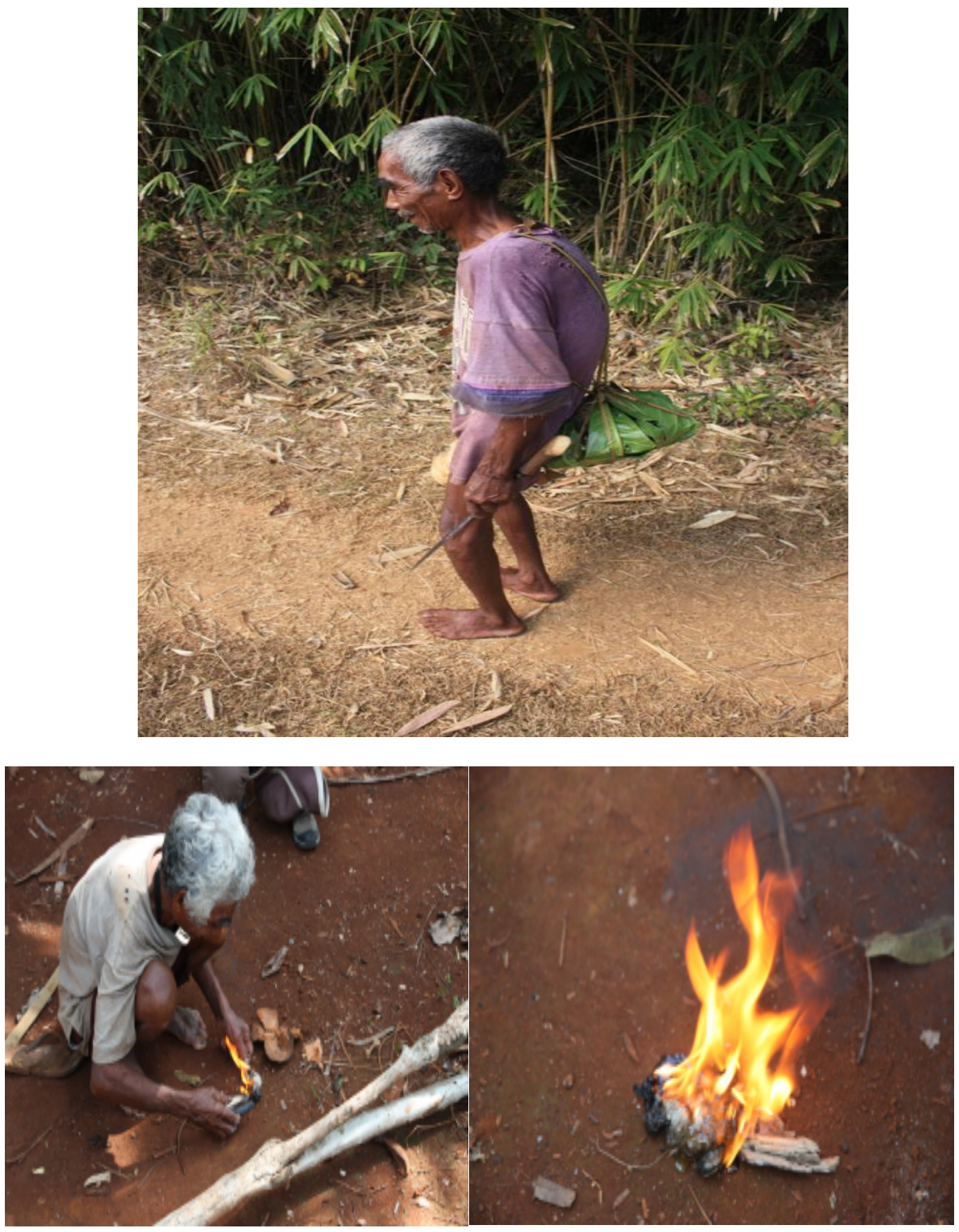

Juan Rodrigo also notes: 'we burn with Saheng and boho... and start with smaller trees on the edge; we burn around, so the wind caries the fire into the centre'. Mauricio Fernandez, a farmer next door, affixes burning saheng at the end of boho and then 'stabs' the dry debris with fire. Most farmers, however, stress they use a longer firebrand made of bamboo, smashed and lit at the end, to 
ensure a safe distance from the fire when igniting field edges (another reason few, if any, farmers burn from the inside out). Winnie, the wife of Danilo Torres-Cruz (see below), also stresses that the initial burn must follow the direction of the wind: "we begin the burn from the bottom so that the wind blows the fire upslope'. One valley over, Lerado Manta, now deceased, explained how he also used a buho firebrand to burn from below as wind pushes the fire upslope: 'we burn from below with the wind blowing up from the seashore, so we first clear the upper sections [as a backburn] before we ignite the lower sections'.

Juan Torres-Cruz, the brother of Danilo, describes a most sophisticated method. He places multiple burning buho bundles at the edge of a field facing the wind so fire is pulled inward along the length of the field to reach the middle, where another line of buho is then ignited to carry fire to the second half of field: 'we place buho in the middle so that winds carry fire over to the next part of field'.

\section{Sequencing of burns (and ash use)}

Most farmers stress that the first burn tends to be the biggest, hottest, and most important for effective planting and ensuring a good yield. In an older second growth fallow, Danilo Torres-Cruz notes:

'with good, thicker wood, a hot fire will burn off the weeds ... [and] produces ash which is salty and slows the growth of weeds. The first rains will wash the salt away and whatever is in the soil will help our plants grow'.

Most farmers stress that the heat and expanse of the initial burn depends on the shape, size, slope, wind direction and type of debris in the field. Danilo notes further: 'If there's a lot of [woody] debris, the fire is hot, and we only need to burn once; a weak burn happens when the wood is not split well and lies close to the ground [to remove undergrowth]'.

Danilo's brother similarly explains that, if felled debris from second growth forest is thickly layered from the ground up (starting with leaves, branches, smaller and then bigger trees), then a powerful, hot burn will often emerge. In other cases, if there is too much debris on a sloped field, a series of smaller, controlled patch burns will run from the top and bottom of a hill to ensure the fire is managed well.

In mature secondary or old growth forest, however, several hot burns are needed in order to completely burn off debris in cleared fields, particularly when larger durable hardwood logs (Ipil (Intsia bijuga), Narra (Pterocarpus indicus) etc), flutes and root structures remain. Indeed, if the farmer's burning strategy fails to clear all the debris in the field (due to insufficient or large-sized 
debris, wet debris or rain), then debris will be collected, piled and burned in one or more locationsa practice known as durok, common among swidden farmers across Palawan. Edward Tomas describes durok: 'We pile smaller to medium size tree debris into the middle or sides of the field. We call this durok. We will burn this for thicker ash deposits in which to plant our crops.'

After a larger durok is burned out, many farmers will plant directly in the fertile ash pocket left behind, or if rain washes and concentrates ash down slope, several water tolerant crops will be planted there (e.g., Talong, Eggplant (Solanum melongena), Kalabasa, pumpkin (Cucurbita maxima). Other larger or permanent debris will be subject to repeat burns.

Pabio Andrada, now deceased, describes how he repeatedly burned larger tree logs so they would not shadow/ squeeze out his rice: 'If I have a bad burn, I will pile debris under any timber and burn it out.... I will pile again until it burns out and will plant in the line of ash'. Similarly, Juanito Cerilio describes the method of piling thinner trees and other debris in a conical manner around larger tree stumps to dry out them out and then set them alight to produce a strong, intense fire to destroy the trunk and its roots - after which he would plant various root crops and maize in the rich ash deposit (see plate 2). Other farmers will collect and apply ash around crops where less debris is burned, and soils are deemed less fertile, or they will add weeds from underbrushing or pulled sometime after the burn.

\section{- Insert Plate 2 here---}

Plate 2: direct planting in burnt out stump

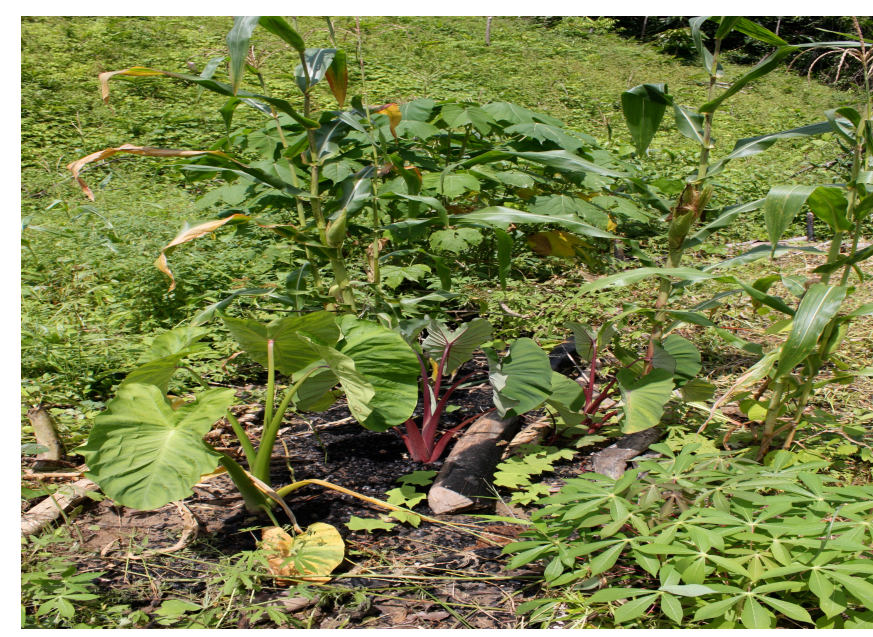




\section{Character and quality of burn}

Fallen trees comprised of harder and softer wood influence the quality of burns, the type of ash, and the colour of smoke. Juanito states that:

'If the smoke is very dark, then you have a hot, strong burn; if the fire is weak then the smoke is white; if the smoke is white, then the field will not be properly burned and cleared; if the smoke is really dark, black, then it means you have a good burn.

The best ash is white ash from hardwoods like Apitong, Narra, Ipil and Katong; trees that are strong and thicker will have good ash; but softer trees [pithy] don't produce much ash because they don't burn very well. If rice is planted in the ash of softer trees, it doesn't grow well and may even die.

We will also transfer ash from certain parts of the field and place it at the roots of newly planted crops.'

\section{Managing fire}

Far from burning fields haphazardly, most Tagbanua use horizontal and vertical 'fire breaks' (gahit) around their fields to ensure fires do not spread beyond plots and burn forests nearby. Manong Flores Sr notes: "We burn away from the kaingin and leave a 1.5 metre firebreak around our field closest to the older forest...”. Another younger farmer, Reymar Villanueva notes “we don't burn the entire field, it is controlled, and we have a brush cut around our kaingin". In other cases, farmers will modify the size of the firebreak depending on the type of forest, with 2 metres reserved for secondary growth and 4 metres reserved for burning near old growth forest, presumably because of the perceived illegality of destroying such forest.

In line with the City's anti-burning discourse, Reymar's older (now deceased) uncle, Joselito Villanueva, stressed:

"You know, the Tagbanua have a careful way of burning... before they burn the kaingin they first make a trail around their field-about 5 metres wide - so that the fire cannot destroy the other forest at the side of the kaingin. This is the way we burn. We have knowledge of how to protect the forest".

The younger farmer, Tomas del Rosario Jr, enthusiastically described his family's dual-form fire break: 'We make gahit around our field but also clear the low hanging branches of trees and any leaves so they don't catch on fire'. 
In addition to a gahit, Aman Salvador used the creative method of filling bamboo (buho) with water which, upon being burned, bursts open and douses any fire trying to go beyond the field's edges. He suggests 'To stop the fire from spreading ...we place buho filled with water around the field so when the fire hits the buho, the water empties out to stop the fire.' Other Tagbanua farmers found different ways to protect their crops from fire damage. Doming Lumaban notes that: 'We place banana leaves and [the] hollow trunk [of banana trees] to wrap around younger trees to protect them from fire...' Villanueva agrees: 'We use the wet 'balot' (hull of trunk) of the banana tree and wrap it around young trees. 'However, acknowledging the technique is not perfect, he explains: 'We burned the kasoy [cashew] trees because the protective cover that we used did not shield enough from the fire... the trunk of the banana tree is hollowed out and placed around the tree...'

Young Reymar Villanueva describes his own crop protection strategy:

We can burn even after planting, but you need a strategy. When you've underbrushed and all the weeds are clean, then you plant the crops directly in a straight line. That way you can easily burn in-between; the crops will not be burn because the weeds are cleaned-out already.

\section{Burning to cleanse (again)}

While a larger hot burn is needed to clear debris, farmers also burn objects to produce smoke to remove pests after planting. Manong Amador notes: 'to get rid of pests we burn our slippers and other rubber in the middle of the field... we also burn different types of seaweed such as kolapo.' Tatay Pabio Andrada also explains that he burns a mix of debris in the middle of fields to ensure that heavy smoke envelopes all of the crops to remove the pest (or disease), dugma, from rice plants (which causes rice stalks to wilt). He asserts that 'smoke coming from the middle of the uma will spread and kill all the pests.' Finally, Erlinda Dimsalang notes that repeat hot burns of felled forest (usually old growth) saves time as such burns permanently remove weeds by destroying the roots/ seeds. She states: 'When we burn, it burns the seeds of the weeds ...that way the weeds will not grow back immediately'.

Despite being only a partial account of Tagbanua fire knowledge and practice, the examples above show how farmers burn with well-honed techniques and environmental knowledge that informs the care, patience and resourcefulness with which clearing and burning strategies unfold. Yet despite some rangers understanding swidden practices, politicians, park managers and some NGOs continue to neglect ethnoecologies of clearing and burning, representing farmers as criminals 
needing enhancement. Although Tagbanua farmers clear and burn forests for swidden on ancestral lands, state and non-state actors continue colonial campaigns of suppressing and criminalizing swidden practices in the context of an expanding environmental bureaucracy on Palawan and elsewhere in the Philippines.

\section{Discussion and conclusion}

As poor uplanders clear and burn forests for life and livelihood, a sense of fear, anxiety and criminality resurfaces in the broader public imaginary. Despite recent efforts by civil society to recalibrate the burden of blame placed upon uplanders, in much of Southeast Asia, state and nonstate actors uphold colonial anti-swidden discourses that criminalise clearing and burning practices through varied governance policies and practices. Under the 'green economy' rubric, regional conservation and development agendas have been reframed as market-oriented, 'green growth' solutions (e.g., natural capital accounting, ecotourism, biofuel production etc) that increasingly intersect with and expand the reach of subnational governance, monitoring and control of swidden in upland areas. The red flames and charred, blackened earth from clearing and burning forests builds on the earlier beliefs concerning lost timber revenue and continues to evoke aversion and negative sentiments among a network of actors whose mandate it is to eradicate swidden agriculture. In the Philippines today, a range of actors governing forests and uplanders therein still invest in and circulate emotive discourses and imagery that represent swidden as unfamiliar, threatening and criminal — what Hall (1997) describes as 'signifying practices': the utterance and actions that produce meaning and that make things mean (61). For centuries, the pejorative language and representations surrounding swidden have stabilised and materialised as practices that not only convey meaning but also structure thoughts and actions concerning who and what is to blame for the spread of fire and deforestation in the uplands. To this day, national conservation discourse continues to represent uplander livelihoods and ways of life as illegitimate in the Philippines.

Despite decades of decentralised governance and progressive indigenous rights and protected area legislation, upland farmers are still told not to burn in relation to a range of issues and circumstances they have little responsibility and control over: avoiding larger burns and escaped fires to conserve biodiversity as 'natural capital'; to protect forest cover for 'eco-tourism' aesthetics; and or to avoid destroying mono-cropped plantations nearby - the maintenance of which only exacerbates livelihood insecurity and poverty among indigenous peoples. The politics of such blame looms large. It draws on and invokes racialized representations of ethnicity and agriculture that casts indigenous uplanders as primitive, degrading, indiscriminate and illegal 'slash-and-burners' of state 
forests (irrespective of whether they hold ancestral titles or not) and lowland migrants as productive, fixed plot sustainable farmers, who, at least initially, also burn vast tracts of forest to claim indigenous lands. Irrespective of whether fire escapes, the fact that scarce and valuable forests are cleared and burned means that burdens of blame invariably inflect and align with degrading representations of uplanders and extensive livelihoods.

As national agencies bemoan swidden's persistence in the southern frontier, it is subnational politicians, local NGOs, and park rangers who give anti-swidden discourses and practices greater local traction through placed-based monitoring and enforcement in village settings. Somewhat beyond the state's purview, municipal actors, rangers and local leaders take on de facto state roles to work as 'swidden brokers' to translate anti-swidden discourses into practice (see Korf and Raeymaekers 2013). Indigenous uplanders who farm swidden on ancestral lands are subject to local disciplining through technologies of control—including zero-burning ordinances, anti-fire workshops, intermittent monitoring against clearing, and various strictures - and ultimately fear the implications of clearing and burning forests and fields. Indeed, the consequences for indigenous peoples (and occasionally migrants) who burn in the wrong area (old growth) at the wrong time (with major winds) can often be significant, with fines potentially being levied. Tagbanua fire angst has thus been reinforced as anti-swidden rhetoric is reproduced locally over several decades.

Yet such broader representations of swidden are not absolute and seldom touch down in a definitive manner. While the monitoring and enforcement of swidden clearing and burning is real and has consequences for farmer rights and livelihood security, migrant and Tagbanua leaders/ rangers tend to broker anti-swidden rhetoric and strictures, softening the unpredictability and force of reprimands among their own. Working on behalf of the provincial DENR, the park or NGOs, local leaders and rangers tend to rework scripts in line with 'atmospheres of consent', or, leniency, based on a local politics of empathy and understanding — notionally consistent with Scott's (1977) 'subsistence ethic' and 'moral economy'. Often today it is farmers themselves, migrant or Tagbanua rangers who monitor and manage swidden as a tolerated crime (Wardell and Lund, 2006; Sugimoto et al., 2014). Given that local brokers may also farm swidden, as shown, they acknowledge that fellow farmers simply do so for food-for hanapbuhay (to make a living). A farmer caught clearing and burning forests on state lands usually only receives a verbal reprimand and rangers and local leaders will usually turn a blind eye to preparing swidden in less mature secondary growth, though this seldom holds true for old growth forests (see Mathews, 2008). Thus, the practice of monitoring of clearing and burning with leniency transpires in close social contexts (see Hall 1997), where inclusions and exclusions unfold with locally brokered consent between families and extended kin, 
among others. Such brokering and enforcement practices reflect the everyday politics of clearing and burning, which temper but do not fully deny swidden's multiple benefits amongst the poor.

Amidst such ambiguous enforcement, many poor Tagbanua continue to cautiously clear and burn forests for swidden on ancestral lands. Despite the burden of blame for clearing forests and escaped fires, at the edges of a protected area, these upland farmers endure by drawing on situated fire ethnoecologies, where complex burning knowledge and practices remain central to the vitality of swidden-based livelihoods. While only a few indigenous households still perform clearing and burning rituals, Tagbanua fire knowledge and practice is necessary, complex and well-integrated in terms of the centrality of swidden to upland livelihoods and social relations; the size and topography of the field; precautionary practices relative to forest type; the type and character of the fallen forest, debris, roots and weeds; the power and direction of wind; the intensity, heat and colour of flames and smoke; alignment with the time of day, heat of the sun, dryness of soils and leaves; the depth, location and quality of ash; the timing of rains and harvests; overall seasonality; and levels of productivity over time.

Despite the care and caution involved in preparing swidden, and its embeddedness in upland life and livelihood, indigenous farmers in the Philippines continue to bear the burden of blame for forest clearing and escaped fires that supposedly lead to forest fires, particularly during El Niño events. State and non-state actors assign blame for forest fires in protected areas, natural capital hotspots and ecotourism spaces to indigenous people's swidden burning practices. Such burdens of blame are pervasive and repeat themselves beyond the Philippines. In Vietnam, Thung et al., (2018) note that the national government, subnational officials and local farmers come to view and represent swidden in contrasting ways. Here national agencies have similarly blamed swidden "as a principal driver of deforestation and forest degradation, and as such a practice to be eliminated" (p.1), but provincial officials recognise its political utility in marking borders in hinterland areas, and local leaders uphold its customary character and value. In the Indonesian frontier, both Thaler et al., (2018) and Thung (2018) show how swidden clearing and burning have become the locus of control for forest governance that should be contending with extensive forest clearing and burning from the expansion of oil palm plantations. As in Palawan, this literature shows how swidden farmers continued to be scapegoated for clearings and conflagrations that stem from 'big capital' agroindustrial practices; that is, from the clearing, draining and burning of larger forest and peatland areas for plantations and other extractive industries (see Astuti, this issue). Despite this, however, we find that the complex character of swidden (shifting, upland, dispersed, regrown etc) and the subsistence and moral economies it is embedded within, make swidden difficult to control and 
eradicate as a practice (see Scott, 2009; Dressler et al., 2019). Among the poor, swidden often persists in the face of long-term constraints, albeit those that are negotiable.

Burdens of blame persist with damaging consequences. Discourses and practices that assign blame endure because of a deep colonial anti-swidden bias that, based on largely redundant scientific forestry and steady-state ecology, suggests swidden clearing and burning is primitive, unproductive, wasteful, and destructive to timber and ecosystem services in supposedly 'intact' upland forests. Such burdens of blame reflect a highly racialized anti-swidden politics of regional and global proportions that now manifest in burgeoning green bureaucracies and political economies; such politics of representation involve crisis narratives that assign blame upon upland farmers for small, annual clearings and burns for swidden but seldom acknowledge the violent and expansive clearing produced by industrial extractivism (e.g., oil palm plantations, mining that subsume swidden plots and family tenure, etc) and its role in escaped fires. In much of Palawan, upland farmers now unjustly feel the weight of such anti-swidden politics and blame despite having little to do with bigger clearings, burnings and carbon emissions. Through a focus that brings reductive representations of clearing and burning into contrast with indigenous farmers' complex fireethnoecologies, we thus continue to advocate for state and non-state actors to afford greater tolerance toward uplanders' right to clear and burn on ancestral lands. Whether state forester or conservationists, dominant actors must recognise clearing and burning practices as integral to nourishing the land, life and livelihood of indigenous farmers in the Philippines and elsewhere in Southeast Asia. The swidden blame game must end. 


\section{References}

Agamben, G. 1998. Homo sacer: Sovereign power and bare life. Stanford: Stanford University Press.

Anda, R. 2015. Summer not all beach in Palawan; it is the season to burn forests. Philippine Daily Inquirer. Retrieved from https://newsinfo.inquirer.net/684378/summer-not-all-beach-in-palawan-itis-the-season-to-burn-forests/2

Bankoff, G. 2004. "The Tree as the Enemy of Man": Changing Attitudes to the Forests of the Philippines, 1565-1898. Philippine Studies, 320-344.

Bankoff, G. 2013. "Deep Forestry": Shapers of the Philippine Forests. Environmental History, 18(3), 523-556.

Boomgaard, P. 2007. Southeast Asia: an environmental history. Abc-clio.

Bryceson, D. 2002. Multiplex livelihoods in rural Africa: recasting the terms and conditions of gainful employment. The Journal of Modern African Studies, 40(1), 1-28.

Carmenta, R., Camelli, F., Zahringer, J., Dressler, W. Between a rock and a hard place: the invisible burdens of uncontrolled fire for smallholders across the forested tropics. Submitted. World Development

Carmenta, R., Coudel, E., \& Steward, A. M. 2019. Forbidden fire: Does criminalising fire hinder conservation efforts in swidden landscapes of the Brazilian Amazon? The Geographical Journal, 185(1), 23-37.

Carmenta, R, Vermeylen, S, Parry, L., Barlow. 2013. Shifting cultivation and fire policy: insights from the Brazilian Amazon. Human Ecology. 41(4), DOI: 10.1007/s10745-013-9600-1

Conklin, H. 1954. Section of anthropology: An Ethnoecological approach to shifting agriculture. Transactions of the New York Academy of Sciences, 17(2 Series II), 133-142.

Conklin, H. 1957. Hanunoo agriculture: A report on an integral system of shifting cultivation in the Philippines. Rome: Food and Agriculture Organisation.

Corson, C., MacDonald, K. I., \& Neimark, B. 2013. Grabbing "green": markets, environmental governance and the materialization of natural capital. Human Geography, 6(1), 1-15.

Dove, M. 1983. Theories of swidden agriculture, and the political economy of ignorance. Agroforestry systems, 1(2), 85-99.

Dove, M. 2011. The banana tree at the gate: a history of marginal peoples and global markets in Borneo. Yale University Press.

Dressler, W. 2009. Old thoughts in new ideas: State conservation measures, livelihood and development on Palawan Island, the Philippines. Ateneo de Manila University Press, Quezon City.

Dressler, W. 2014. Green governmentality and swidden decline on Palawan Island. Transactions of the Institute of British Geographers, 39(2), 250-264.

Dressler, W. 2019. Governed from above, below and dammed in between: The biopolitics of (un) making life and livelihood in the Philippine uplands. Political Geography. 73, 123-137

Dressler, W., \& Fabinyi, M. 2011. Farmer gone fish'n? Swidden decline and the rise of grouper fishing on Palawan Island, the Philippines. Journal of Agrarian Change, 11(4), 536-555. 
Dressler, W., Smith, W., \& Montefrio, M. J. 2018. Ungovernable? The vital natures of swidden assemblages in an upland frontier. Journal of Rural Studies, 61, 343-354.

Dressler, W., Wilson, D., Clendenning, J., Cramb, R., Keenan, R., Mahanty, S., ... \& Lasco, R. D. 2017. The Impact of swidden decline on livelihoods and ecosystem services in Southeast Asia: A review of the evidence from 1990 to 2015. Ambio, 46(3), 291-310.

Dressler, W., \& Pulhin, J. 2010. The shifting ground of swidden agriculture on Palawan Island, the Philippines. Agriculture and Human Values, 27(4), 445-459.

Dressler, W., de Koning, J., Montefrio, M., \& Firn, J. 2016. Land sharing not sparing in the "green economy": The role of livelihood bricolage in conservation and development in the Philippines. Geoforum, 76, 75-89.

Eder J and Fernandez J. 1996. Palawan at the Crossroads. Quezon City: Ateneo de Manila University Press,

Eder, J, \& Evangelista, O., 2015. Palawan and its Global Connections. Quezon City: Ateneo University Press.

Eloy, L., Hecht, S., Steward, A., and Mistry, J. 2019. Firing up: Policy, Politics and Polemics under New and Old Burning Regimes. The Geographical Journal 185 (1), 2-9.

Entman, R. 1993. Framing: Toward clarification of a fractured paradigm. Journal of communication, 43(4), 51-58.

Fletcher, R., Dressler, W. H., Anderson, Z. R., \& Büscher, B. 2018. Natural capital must be defended: green growth as neoliberal biopolitics. Journal of Peasant Studies, 1-28.

Fox, J., Fujita, Y., Ngidang, D., Peluso, N., Potter, P., Sakuntaladewi, N., Sturgeon, J., and Thomas, D., 2009. Policies, political-economy, and swidden in Southeast Asia. Human Ecology 37(3), 305322.

Fox, R., 1954. Tagbanua Religion and Society. Unpublished PhD. Thesis. University of Chicago, Chicago.

Gatmaytan, D. 1992. Land rights and land tenure situations of indigenous peoples in the Philippines. Philippine Natural Resources Law Journal. 5 (1), 5-41.

Haenn, N. 1999. The power of environmental knowledge: Ethnoecology and environmental conflicts in Mexican conservation. Human Ecology, 27(3), 477-491.

Hall, D., \& Hirsch, S. Li 2011. The powers of exclusion: land dilemmas in Southeast Asia. National University Press.

Hall, S. 1985. Signification, Representation, Ideology: Althusser and the Post-Structuralist Debates. Critical Studies in Mass Communication. 2(2), 91-114

Hall, S. 1997. Representation: Cultural representations and signifying practices. Vol. 2. Sage Publications.

Hall, S. 2011. The Neoliberal Revolution. Cultural Studies. 25(6), 705-728

Korf, B., \& Raeymaekers, T. 2013. Violence on the Margins. States, Conflict and Borderlands. Palgrave, MacMillan

Kull, C. 2004. Isle of fire: the political ecology of landscape burning in Madagascar. University of Chicago Press. 
Lawrence, D., \& Schlesinger, W. H. 2001. Changes in soil phosphorus during 200 years of shifting cultivation in Indonesia. Ecology, 82(10), 2769-2780.

Leach, M., \& Mearns, R. 1996. Environmental change and policy. The Lie of the Land: Challenging Received Wisdom on the African Environment; Imperial College: London, UK, 440-475.

Leach, M \& Fairhead, J. 2000. Fashioned forest pasts, occluded histories? International environmental analysis in West African locales. Development and Change 31, 35-59.

Mallari Jr, D. T., \& Cinco, M. 2016. 5-hour fire hits Mt. San Cristobal in Laguna; 'kaingin' blamed. Philippine Daily Inquirer. Retrieved from https://newsinfo.inquirer.net/779530/5-hour-fire-hits-mtsan-cristobal-in-laguna-kaingin-blamed

Masipiqueña, A., Persoon, G., \& Snelder, D. 2003. The use of fire in Northeastern Luzon (Philippines): Conflicting views of local people, scientists, and government officials'. Indigenous environmental knowledge and its transformations: Critical anthropological perspectives, ed. Roy Ellen et al.(Amsterdam: Harwood Academic Publishers, 2000), 177-212.

Mathews, A. S. 2008. State making, knowledge, and ignorance: translation and concealment in Mexican forestry institutions. American Anthropologist, 110(4), 484-494.

Mertz, O., Leisz, S. J., Heinimann, A., Rerkasem, K., Dressler, W., Pham, V. C., ... \& Padoch, C. 2009. Who counts? Demography of swidden cultivators in Southeast Asia. Human Ecology, 37(3), 281-289.

Mier, A. (2014, August 3). Bush fire destroys 6,000 hectares of forest, grasslands. Philippine Daily Inquirer.

Montefrio, M., \& Dressler, W. 2016. The green economy and constructions of the "idle" and "unproductive" uplands in the Philippines. World Development, 79, 114-126.

Mosse, D., \& Lewis, D. 2006. Theoretical approaches to brokerage and translation in development (Vol. 1, pp. 1-26). Bloomfield, CT: Kumarian Press.

Nano, J. F. 1939. Kaingin laws and penalties in the Philippines. Philippine Journal of Forestry, 2(2), 87-92.

Nazarea, V. 1999. Ethnoecology: Situated Knowledge/Local Lives. University of Arizona Press. Tucson.

Nigh, R. 2008. Trees, fire and farmers: making woods and soil in the Maya forest. Journal of Ethnobiology, 28(2), 231-244.

Novellino, D. 2011. Toward a "common logic of procurement": Unravelling the foraging farming interface on Palawan Island. In: Barker, G., Janowsky (Eds.), Why Cultivate? McDonald Institute for Archaeological Research, Cambridge, pp. 105-119.

Novellino, D., \& Dressler, W. 2009. The role of "hybrid" NGOs in the conservation and development of Palawan Island, The Philippines. Society and Natural Resources, 23(2), 165-180.

Peters, W. J., \& Neuenschwander, L. F. 1988. Slash and burn: farming in the Third World forest. Caldwell: University of Idaho Press.

Pham, T., Moeliono, M., Wong, G., Brockhaus, M., and Le Ngoc Dung. 2018. The Politics of Swidden: A Case Study from Nghe An and Son La in Vietnam. Land Use Policy, March.

Phil-WAVES. 2014. Ecosystem Accounts in Southern Palawan, the Phil-WAVES implementation plan for Southern Palawan. Wealth Accounting and the Valuation of Ecosystem Services, 14 February. 
Population Center Foundation. 1980. Kaingineros: the Philippine boat people. Makati: Population Center Foundation.

Pulhin, J. M., Dizon, J. T., Cruz, R. V. O., Gevana, D. T., \& Dahal, G. 2008. Tenure reform on Philippine forest lands: assessment of socio-economic and environmental impacts. CIFOR Working Paper, 2008

Pyne, S. 1997. Vestal fire: an environmental history, told through fire, of Europe and Europe's encounter with the world. Seattle: University of Washington Press.

Quitasol, K. 2016. Parts of Mt. Pulag burned anew for kaingin. Philippine Daily Inquirer. Retrieved from https://newsinfo.inquirer.net/793609/parts-of-mt-pulag-burned-anew-for-kaingin

Rambo, T. 1983. Fire and the Energy Efficiency of Swidden Agriculture. East-West Environment and Policy Institute, Honolulu, Hawaii, USA.

Sajise, P. E. 1998. Forest policy in the Philippines: A winding trail towards participatory sustainable development $A$ step toward forest conservation strategy: Current status on forests in the Asia-Pacific region. Tokyo: The Institute for Global Environmental Strategies.

Scott, G. 1979. The evolution of the socio-economic approach to forest occupancy (kaingin) management in the Philippines. Philippine Geographical Journal, 23(2), 58-73.

Scott, J. 1977. The moral economy of the peasant: Rebellion and subsistence in Southeast Asia. New Haven, CT: Yale University Press.

Scott, W. 1974. The discovery of the Igorots: Spanish contacts with the pagans of Northern Luzon. Manila: New Day Publishers.

Sivaramakrishnan, K. 1999. Modern forests: Statemaking and environmental change in colonial eastern India. Stanford: Stanford University Press.

Smith, W. 2018. Weather from incest: The politics of indigenous climate change knowledge on Palawan Island, the Philippines. The Australian Journal of Anthropology, 29(3), 265-281.

Smith, W., \& Dressler, W. 2017. Rooted in place? The coproduction of knowledge and space in agroforestry assemblages. Annals of the American Association of Geographers, 107(4), 897-914.

Smith, W., \& Dressler, W. 2019. Governing vulnerability: The biopolitics of conservation and climate in upland Southeast Asia. Political Geography, 72, 76-86.

Smith, W., \& Dressler, W. (forthcoming). Forged in flames: Indigeneity, forest fire and geographies of blame in the Philippines. Postcolonial Studies,

Sugimoto, A., Pulhin, J., Inoue, M., 2014. Is Recentralization Really Dominant? The Role of Frontline Foresters for Institutional Arrangements in the Philippines. Small-scale Forestry. 13,1832000

Tacconi, L. 2016. Preventing fire and haze in Southeast Asia. Nature Climate Change 6:640-643

Thaler, G., and Anandi, C. 2017. "Shifting Cultivation, Contentious Land Change and Forest Governance: The Politics of Swidden in East Kalimantan." Journal of Peasant Studies 44, 5, 106687

The World Bank. 2012. Inclusive green growth: The pathway to sustainable development.

Washington D.C.: Author.

Therik, T. 2000. The role of fire in Swidden cultivation: A Timor case study (Indonesia). In ACIAR Proceedings. ACIAR. 
Thung, P. 2018. A Case Study on the Persistence of Swidden Agriculture in the Context of Post2015 Anti-Haze Regulation in West-Kalimantan. Human Ecology 46, 2, 197-205.

To, P., \& Dressler, W. 2019. Rethinking 'Success': The politics of payment for forest ecosystem services in Vietnam. Land Use Policy, 81, 582-593.

United Nations Environment Programme (UNEP). 2011. Towards a green economy: Pathways to sustainable development and poverty eradication. Retrieved from www.unep.org/greeneconomy on March 3, 2013.

Vasan, S. 2002. Ethnography of the forest guard: contrasting discourses, conflicting roles and policy implementation. Economic and Political Weekly, 4125-4133.

Wardell, D. A., \& Lund, C. 2006. Governing access to forests in northern Ghana: micro-politics and the rents of non-enforcement. World Development, 34(11), 1887-1906.

Warner, K., 1979. Walking on two feet: Tagbanwa Adaptation to Philippine Society. Unpublished PhD Dissertation. Manoa: University of Hawaii at Manoa

West, P. 2006. Conservation is our government now: the politics of ecology in Papua New Guinea. Durham: Duke University Press.

Whitford, H. N. 1911. The forests of the Philippines. Manila: Bureau of Printing, 1909-1911 